Ethiopian Journal of Environmental Studies \& Management 7(3): 319 - 326, 2014.

ISSN:1998-0507

doi: http://dx.doi.org/10.4314/ejesm.v7i3.12

Submitted: March 3, 2014

Accepted: May 5, 2014

\title{
INFORMAL ACTIVITIES DELIVERING FORMAL HOUSING: A CASE STUDY OF HOUSE-BUILDING INDUSTRY IN ILE-IFE, NIGERIA OLAYENI, K.P.
}

\section{Department of Architecture, Obafemi Awolowo University, Ile-Ife, Nigeria}

Email: pk_olayeni@yahoo.co.uk

\begin{abstract}
The challenge of housing provision in the developing countries is quite enormous. Various efforts at addressing these problems have seen both the institutional and individual intervention in provision of residential housing. Informal players in the house-building industry are on the increase though their intervention in housing provision has been downplayed as not having the required depth. In an effort to understand how informal activities in the housing subsector of the construction industry contribute to provisions of housing, this paper looks into the activities in the house-building industry and the product emanating from such activities. Self-administered questionnaires were given to 242 house owners in the ancient city of Ile-Ife to elicit quantitative data. Also notable members of building artisanal associations were interviewed to obtain qualitative data. All data were analysed using descriptive statistical tools and content analysis for quantitative and qualitative data respectively. Result showed that housing provision activities at the local level undergoes different stages of informal interactions and processes, yet the product were formal housing unit which were in no way inferior to the institutionalized official government housing. Enabling environment should therefore be provided for these informal players in the house-building industry to contribute their quota in increasing housing unit in these areas.
\end{abstract}

Key words: artisans, house owner, house-building, informal housing

\section{Introduction}

Housing is defined as buildings or other shelters in which people live, a dwelling (Kabir and Bustani, 2008). It represents one of the basic human needs, social, economic and health fabric of all nations (Ademiluyi and Otun, 2000). Housing is seen as a key determinant of quality of life that can be measured at individual, household and community levels (Campbell, Converse and Rodgers, 1976). It is also recognized all over the world as one of the basic necessities of life and a pre-requisite to survival of man (Onibokun, 1983; Salau, 1990).

Housing has been a major concern of individual, families, group and government since the dawn of urban civilization (Aliyu et al., 2011). This has led to housing crisis in most developing countries especially in the wake of unplanned rural-urban migration. Housing shortages are the norm rather than the exception in most of these countries despite some frantic effort at mitigating this problem. Actually, housing problem is one of the global problems with grave and rising challenges (Ademiluyi, 2010). This rapid rise in what is termed urbanization has made major cities to be unable to provide basic shelter for the teeming population. Actually, according to Tesfaye (2007), urbanization and demand for houses are positively correlated. The resulting increase in demand for houses are still largely unmet in most of the developing countries despite various policies and programmes to increase the housing stock (Tipple and Willis, 1991).

In Nigeria, the housing crises is even increasing where the level of production of housing according to Anthonio (2002) is only two dwelling units per thousand people, compared to the required rate of $8-10$ dwelling units per 1,000 population recommended by the United Nations. Housing provision problems in Nigeria had been documented severally in earlier studies and observation (Agboola, 1998; Mabogunje, 2003; Olatubara, 2008; Onibokun 1990). The necessity of shelter to everyone has made providing adequate housing a major concern. It is 
a concern to successive Nigerian government even before independence. The National Development Plans (NDPs) spanning 1962 to 1985 and the National Rolling Plans (NRPs) from 1990 to date were some of the effort by the government at ameliorating the problem. Public housing, as the house provided by the government at various level is known (Ikejiofor, 1999) were inadequate in meeting the identified need (Akeju, 2007), and mismanaged (Ogunshakin and Olayiwola, 1992).

The private sector of the economy foray into housing provision is gaining some momentum in Nigeria. This attempt by the organized private sector characteristically is limited to the highly urbanized cities of Lagos, Abuja and Port Harcourt and some of their adjoining towns (Gbadeyan, 2011; Henshaw, 2010; Ibem and Aduwo, 2012).

Apart from the public intervention into housing problem and the organized private sector, private individual efforts are growing in the area of housing provision especially in hinterland towns and cities of Nigeria. These efforts of "Housing Themselves" (Magigi and Majani, 2006) are efforts of individuals to construct their own house from their personal initiative and savings which take over a long period of time (Magigi and Majani, 2006). It is also seen as alternative to obtain better housing in informal settlement. Individual housing themselves is mostly equated with informal housing for mostly low and middle income groups (Keivani and Werna, 2001).

The three efforts at producing residential housing are subdivided into two - conventional and unconventional housing provision. The former has distinct actors comprising formal planning authorities, banks, building and land development companies, and other governmental agencies involving in strictly formal activities at providing housing (Drakakis - Smith, 1981). Public and private sector falls under this division. The latter has unofficial or informal actors comprising individual house owners, different artisan employed to work on the site using labour intensive methods and building incrementally.

Informal housing is a product of informal construction activities (Wells, 2001) which some authors defined as all unplanned or unregulated housing or building activities (UNCHS/ILO,
1995). It is produced further still by unregulated actors who are individuals or enterprises not registered and regulated by government to offer protection and to the workers in such area as terms and condition of works. These actors supply skill, labour and contribute in other ways to the output of housing and construction sectors.

Ahsan and Quamruzzaman (2009) submitted that informal housing, distinguished from formal and organic housing (Sivam, 2003) consist of illegal development of unapproved, unregulated units of housing. Furthermore, this type of housing happens because of unaffordability or sometimes unavailability of housing in legal market.

Informal housing is seen to have unsecure tenure and low standard of facilities and infrastructure including running water supply and power (Siethuraman, 1985). To sum it up, informal housing is seen as houses that are built by low or medium income groups outside the framework of formal law for constructing housing, using less expensive construction materials and without meeting the required building codes (Johnson, 1987).

Actors that are found predominantly within the informal housing spheres include the direct actors; the individual house owners, skilled informal artisans like masons, carpenters, draughtsmen, survey technicians, electrical technicians and painters (Amole and Olayeni, 2011) and also ancillary actors majorly labourers, transporters and food vendors. In all, they are informal actors not because of anything but that they are of small unregistered enterprises, individuals, self-employed - they supply their skills and labour to the output of the construction sector mainly engaging in housing and building construction activities (Mlinga and Wells, 2002).

Mlinga and Wells (2002) and Nguloma (2006) observed that houses provided by low and middle income group as informal housing, a product of largely artisanal system of production (Makelle, Mesaki and Victor 2011) brought about by individual savings over a long period of time because access to formal mortgage finance is difficult and almost impossible. These efforts has been seen to lead to propagating informal settlements in most cities of developing countries (Sethuraman, 1985) and the proliferation of substandard and low qualities houses. 
The outputs of these efforts by individuals, some studies opined are without official permit, outside the system of planning and control (Syagga and Malombe, 1995). Despite all these issues raised, that is the informality of planning, approval, financing actors and processes, this type of housing are on the increase and are contributing their quota in adding to the housing stock of most developing countries.

\section{Methodology}

This study was conducted in the ancient city of Ile-Ife which is a university city in south west Nigeria. The city has about 500,000 people according to the national population census conducted in the year 2006. Both the survey and qualitative research methods were employed for this study. The former used the questionnaire as a tool for eliciting data from house owners in the study area who were used as the unit of data collection. The latter used an interview schedule in obtaining information from some selected artisans in the house-building industry. Fifteen percent $15 \%$ of the estimated 1,613 houses built between 2003 and 2007 in all the 9 residential areas were randomly selected. These sums up to 243 houses and questionnaires were administered to the house owners. The qualitative aspect of the study involved in-depth interviews of seven notable members from four of the house-building trade's associations namely, the survey technicians, draughtsmen, masons and carpenters' association.

Questions asked the house owners included information about access to land and land acquisition types of actors involved in the construction of the houses, issues about tenure and regularization of titles to the lands, submission and approval of building plan including the personnel involved in the drawing and approving the plans. The owners were also asked about sourcing building materials, level of incremental construction as well as the formality or otherwise of the house owner engagement of the other actors who worked on the building site. The order of construction activities was also asked as well as their perception of the quality of the work done by the other major actors who were involved in the constriction processes. The socio-economic characteristics of the house owner were also obtained through the questionnaire. The data obtained were analysed descriptively.

For the selected workmen, the in-depth interview schedule made them to give information about their age, gender and area of specialization in the house-building industry. Educational level, types of and level of training and working experience were the other information the interviewer obtained from these actors. The interview concluded by obtaining information about the workmen's organization like the structure, membership, norms and value and operational coverage and network. All these data were subjected to content analysis.

\section{Results and Discussion}

\section{Socio Economic Characteristics of Actors}

This study identified individual house-owner at the center of the house building activities. From the data collected from them, four other actors were seen to be highly involved in the construction activities; they are the masons and the carpenters (they were involved in $100 \%$ of the houses built), survey technicians (they were involved in $98.7 \%$ of the houses built) and the draughtsmen (they were involved in $74.2 \%$ of the houses built). Apart from these four artisans, construction labourers also were involved in all the houses built while architect's services were employed by less than $3 \%$ of the house owners. From the above information, the client (house owner), draughtsmen, survey technicians, masons and bricklayers were the actors the study was interested in.

From table 1, it is clear that there are more male house owners $(80.9 \%)$ to female $(19.1 \%)$. The modal age of these house owners ranges between 40years and 59years (73.3\%). Majority of the house owner $(70 \%)$ has at least a diploma certificate and or a university degree. Nineteen percent of the house owner has either a primary school or secondary school leaving certificate. With this level of education attained, it was not difficult to discover that employment wise, $29.7 \%$ works as administrator or civil servant. Others being teachers $(20.8 \%)$, lecturers $(3.8 \%)$, professionals and business men $(21.2 \%)$, the selfemployed and artisans (14.8\%), clergy (2.5\%) and retires $(7.8 \%)$. The average monthly income of the house owner showed that majority of them falls within the middle income earner group with 
about $42 \%$ earning above $\$ 50,000$, another $47 \%$ earns between $\$ 21,000$ and $\$ 50,000$ and $10 \%$ of them earns below $\$ 20,000$.

For the other four identified artisans working for and interacting with the house-owners to selfbuild their houses their houses, it was seen that majority were male $100 \%$ except for the draughtsmen with $10 \%$ female. The academic qualification attained by these actors ranges between none among the masons and carpenters and national diploma among the draughtsmen and survey technicians. All (100\%) of these artisans were self-employed, small scale enterprises. They get their commission either from the houseowners or can be called by friends or colleagues to work on a building project.

Table 1: House owners (client)

\begin{tabular}{|c|c|c|c|c|}
\hline Age & Gender & $\begin{array}{l}\begin{array}{l}\text { Highest level of } \\
\text { education }\end{array} \\
\end{array}$ & Employment & $\begin{array}{l}\text { Average monthly } \\
\text { income }\end{array}$ \\
\hline $14 \%: 21-39 y r s$ & $\begin{array}{l}80.9 \% \\
\text { Male }\end{array}$ & $0.4 \%$ - None & $\begin{array}{l}21.2 \%: \text { Professional } \\
\text { and businessmen }\end{array}$ & $\begin{array}{l}10.6 \% \text { earns below } \\
\$ 20,000\end{array}$ \\
\hline $37.3 \%: 40-49 y r s$ & $\begin{array}{l}19.1 \% \\
\text { Female }\end{array}$ & $2.1 \%$ - Pry School & $\begin{array}{l}\text { 29.7\%: Administrator } \\
\text { \& civil servant }\end{array}$ & $\begin{array}{l}47.4 \% \text { earns btw } \\
\$ 21,000-\$ 50,000\end{array}$ \\
\hline $36 \%: 50-59 \mathrm{yrs}$ & & 16.9\%-Sec. School & $\begin{array}{l}\text { 20.8\%:Teachers } \\
\text { (basic \& post basic) }\end{array}$ & $\begin{array}{l}30.1 \% \text { earns btw } \\
\$ 51,000-\$ 100,000\end{array}$ \\
\hline 12.7\%:60yrs\&above & & $\begin{array}{l}70 \%-\text { Tertiary } \\
\text { institution } \\
10.6 \% \text { - others }\end{array}$ & $\begin{array}{l}14.8 \% \text { Self employed } \\
\& \text { artisans } \\
3.8 \% \text { :Lecturers } \\
2.5 \% \text { : Clergy } \\
7.8 \% \text { : Retirees }\end{array}$ & $\begin{array}{l}11.9 \% \text { earns above } \\
\# 100,000\end{array}$ \\
\hline
\end{tabular}

Table 2: Artisans Characteristics

\begin{tabular}{|c|c|c|c|c|c|}
\hline & Gender & Age & Academic qualification & Training & Employment type \\
\hline \multirow[t]{2}{*}{ Masons } & \multirow[t]{2}{*}{ 100\% Male } & Between early & Minimum: None & Between & SSSE \\
\hline & & twenties \& 60years & $\begin{array}{l}\text { Maximum: Secondary } \\
\text { school }\end{array}$ & and 3years & $\begin{array}{l}\text { *Small Scale Self } \\
\text { Employed }\end{array}$ \\
\hline \multirow[t]{2}{*}{ Carpenter } & \multirow[t]{2}{*}{$100 \%$ Male } & Between 25years & Minimum: None & Between 3 & SSSE \\
\hline & & and 75years & $\begin{array}{l}\text { Maximum: Secondary } \\
\text { school }\end{array}$ & and $31 / 2$ years & \\
\hline \multirow[t]{2}{*}{$\begin{array}{l}\text { Survey } \\
\text { technician }\end{array}$} & \multirow[t]{2}{*}{$100 \%$ Male } & \multirow[t]{2}{*}{$\begin{array}{l}\text { Between 30years } \\
\text { and 55years }\end{array}$} & $\begin{array}{l}\text { Minimum: Secondary } \\
\text { School }\end{array}$ & \multirow[t]{2}{*}{$\begin{array}{l}\text { Minimum of } \\
\text { 3years }\end{array}$} & SSSE \\
\hline & & & $\begin{array}{l}\text { Maximum: Ordinary } \\
\text { national diploma }\end{array}$ & & \\
\hline \multirow[t]{2}{*}{ Draughtsmen } & \multirow[t]{2}{*}{$\begin{array}{l}90 \% \text { Male } \\
10 \% \text { Female }\end{array}$} & \multirow[t]{2}{*}{$\begin{array}{l}\text { Between 30years } \\
\text { and 50years }\end{array}$} & $\begin{array}{l}\text { Minimum: Primary } \\
\text { school }\end{array}$ & \multirow[t]{2}{*}{3 years } & SSSE \\
\hline & & & $\begin{array}{l}\text { Maximum: Ordinary } \\
\text { national diploma }\end{array}$ & & \\
\hline
\end{tabular}

\section{Interrelationship of the Different Actors}

All $(100 \%)$ of the house owners got the services of the identified artisans informally. Some personally $(23.7 \%$ ), or through friends $(53.0 \%)$ through connection in religious or social organization $(12.7 \%)$ and for some it was one artisan that linked the owners to another artisan $(3.0 \%)$. This is contrary to what is obtained in the formal construction sector. No documented or written contractual agreement other than the bargaining power of the owner who sometimes may bargain with more than three artisans doing the same trade before agreeing with one. All the artisans interviewed were unanimous on the fact that connections and contacts were necessary for obtaining a job and commission in the building industry. In the word of one of the masons interviewed,

"... connection is the important thing that brings us in contact with the house-owner. It may be through one friend or a social organization member. Sometimes it may be someone I have worked for before who will introduce me to a new client..." 
From access to the land by buying and surveying it out, the would-be house owner keeps relating with these other actors in such areas as bargaining for fees, payment, supplying of materials to the site and even complaining of job not done according to agreed terms.

In determining how formal or informal this interrelationship and engagement were between the house owner (clients) and these identified actors working to bring the aspiration of the house owner to reality, the house owner's response showed that for interactions with most of the other actor (it is overwhelmingly informal)
- 77.5\% (masons), $78.8 \%$ (carpenter), $53.0 \%$ (draughtsmen) and $51.7 \%$ (survey technician). It was also discovered that two artisans that were involved with some paper work, that is the survey technician and draughtsmen has some level of formality $-47.4 \%$ and $22.1 \%$ respectively. This was due to the fact that they also involved the local planning authority for the survey plan and building drawing.

In all, it was seen that the interactions in the processes that leads to housing provision is majorly informal though with some level of informality.

Table 3 Clients' Interaction with Artisans

\begin{tabular}{lllll}
\hline & Masons & Carpenter & Draughtsmen & Survey technician \\
\hline Very formal & $2.5 \%$ & $3.4 \%$ & $8.1 \%$ & $21.6 \%$ \\
Fairly formal & $19.9 \%$ & $17.8 \%$ & $14.0 \%$ & $25.8 \%$ \\
No formal at all & $77.5 \%$ & $78.8 \%$ & $53.0 \%$ & $51.7 \%$ \\
Not applicable & - & - & $25.0 \%$ & $0.8 \%$ \\
\hline
\end{tabular}

\section{Access to Land and Tenure}

Studies on informal housing sector showed that there is largely insecurity of land tenure (Tsenkova, 2009) because according to one study (Ahsan and Quamruzzaman, 2009), the failure or hardship to get access to land and increased rural urban migration.

Access to land and secured tenure has been seen as important to provision of adequate shelter be it in rural or urban areas (Home and Lim, 2004). According to Magigi and Majani (2006), informal land transactions follow a pattern where there is a deal between the buyer and seller and some local people who stands in as witnesses. In the study area, the situation is not different as such. When the house owners were asked about acquisition of their land

Table 4 Acquisition of the land

\begin{tabular}{ll}
\hline Inherited & $5.5 \%$ \\
\hline Purchased & $91.5 \%$ \\
Leased & $1.3 \%$ \\
As a gift & $1.7 \%$ \\
\hline
\end{tabular}

Majority $91.5 \%$ purchase the land informally while 5.5\% inherited the land from their families. Others $(1.7 \%)$ got their land as gift while $1.3 \%$ said the land was leased to them. Those who bought the land got to know about the availability of the land largely through informal means;
$18.6 \%$ through family connections, $46.2 \%$ through friends and $23.3 \%$ through land vendors called survey technicians. Draughtsmen 2.5\% and cooperative societies $2.1 \%$ were the other sources of information about the land purchased.

As a means of regularizing the land purchased, $99.2 \%$ of the house-owner had survey plan while $0.4 \%$ did not have. The survey plan done is acceptable with the local planning authority. The survey plans produced were of two types, namely the state government record copy and the ordinary survey plan. The difference being the extent to which the plan was processed and the amount paid for the processing. The record copy is processed through to the state government where the state's surveyors general do the proper and final documentation of the land and signs on behalf of the government. The fees payable by the house owners is generally more than the ordinary copy which is only processed through to the local government planning authority and attracts much lesser fees. The record survey is the only of the two types that can be used to obtain Certificate of Occupancy ( $\mathrm{C}$ of $\mathrm{O}$ ) and with this a house owner can use the document to obtain loan facilities from financial institution. $55.1 \%$ of the house owners had the ordinary copy of the survey while $44.1 \%$ had the record copy. 
Informal Activities Delivering Formal Housing: A Case Study................ OLAYENI, K.P.

Whether ordinary copy or the record copy, it was noted that though the process of acquiring the land started informally most of the house owners processed their land title deeds to various degree of formality which gives them formal legal (status contrary to what some studies affirmed).

\section{Government Approval}

Whereas some literature on self-build informal housing discussed the issue of lack of government approval for houses built. This study discovered that:

Most of the house owners had a building plan produced for them by draughtsmen $(68.2 \%)$, survey technician $(11.9 \%)$, engineer $(2.5 \%)$ and others $(17.2 \%)$ which included an architect or a mason. Out of those that had a building plan drawn before constructing, $97.0 \%$ of them eventually submitted their plans for local planning authority for approval while only $1.3 \%$ did not. This is a reflection that though the houses were self-built, they still had some sort of understanding of what needs to be done administratively. $95.8 \%$ of those who processes their building plan to the planning authority eventually obtained approval from the authority giving them legal backing for the structures they were erecting and having such approval connote formality unlike what some studies observed (Tsenkova, 2009).

\section{Building Construction Process}

When some studies claimed that informal houses built by individual were done incrementally (Boamah, 2010; Green and Rojas, 2008). This study also discovered that most of the house owners built incrementally. This was observed when the owners were asked if certain construction works were completed before moving in to the house.

Table 5: Approval of building plan

\begin{tabular}{lll}
\hline & Yes & No \\
\hline $\begin{array}{l}\text { Did you have a building plan } \\
\text { before starting construction }\end{array}$ & $90.7 \%$ & $8.5 \%$ \\
$\begin{array}{l}\text { Was the building plan submitted } \\
\text { for approval }\end{array}$ & $97.0 \%$ & $1.3 \%$ \\
$\begin{array}{l}\text { Did the town planning authority } \\
\text { eventually approve the plan }\end{array}$ & $95.8 \%$ & $2.5 \%$ \\
\hline
\end{tabular}

Table 6: Level of completion of construction

\begin{tabular}{lll}
\hline & Yes & No \\
\hline Electrical work yet to be done & $39.4 \%$ & $60.6 \%$ \\
Floor finish yet to be done & $35.6 \%$ & $64.4 \%$ \\
Painting yet to be done & $80.9 \%$ & $19.1 \%$ \\
Plumbing yet to be done & $41.9 \%$ & $58.1 \%$ \\
$\begin{array}{l}\text { Doors and windows to be fixed } \\
\text { Plastering to be done }\end{array}$ & $25.0 \%$ & $75.0 \%$ \\
$\begin{array}{l}\text { Building completed with no } \\
\text { more work }\end{array}$ & $6.8 \%$ & $70.3 \%$ \\
\hline
\end{tabular}

Only $6.8 \%$ claimed to have totally finished all the construction work before moving in. Others had different task of construction unfinished before moving in and they were only completing the task as they were dwelling in the house. $73.7 \%$ of the house owners did say that there were series of stop-start-stop in the construction processes. 50\% of them stopped construction activities for between two and four times and about $16.17 \%$ stopped once.

This shows a high level of incremental construction which allowed owners of these houses to secure funds and build at the rate convenient for them. Workers were mobilized to site at such time determined by the clients and as such no rigid schedule of work was followed. Level of "completion" differs from one house owners to the other before moving into the building and as such construction activities continued even when the owners had moved into the building with his/her family.

\section{Conclusion}

This study has found that housing production is going on at different level in the study area. The involvement of different actors in the housebuilding industry is evidently seen also, though in the study area these actors are mostly informal artisans working with the clients. Various processes leading to the completion of the houses in the study area were investigated and the results showed that largely the informal building processes were the order of the day. However some of the processes that required formal official inputs were not left undone. Despite the informality of the actors, their rule of engagements and the processes of construction, the houses produced cannot be categorized as informal housing, they are responses of 
individuals to the challenges of housing provisions which official government response is incapable to meet.

\section{References}

Ademiluyi, I.A (2010). Public Housing Delivery Strategies in Nigeria: A Historical perspective of policies and programme. Journal of Sustainable Development in Africa 12(6), 153-161

Ademiluyi, I.A. and Otun, W.O (2010). The Integration of Income Generating Activities in Low Cost Housing Units to reduce Poverty in Developing Countries. Pakistan Journal of Social Science 7(3): 187 - 199, 2010.

Agboola, T. (1998). The Housing of Nigeria - A Review of Policy Development and Implementation Research Report; No.14, Development Policy Centre, Ibadan.

Ahsan, R. and Quamruzzaman, J.M. (2009): Informal Housing and Approaches towards the Low-income

Akeju, A.A. (2007). Challenges to providing affordable housing in Nigeria. Paper presented at the $2^{\text {nd }}$ Emerging Urban Africa International Conference on Housing Finance in Nigeria, held at Shehu Yar' adua Centre Abuja, October 17-19, 2007.

Aliyu, A.A., Kasim, R. and Martin, D. (2011). Factors affecting housing development in Makama Jahun area of Bauchi metropolis, Nigeria. International Journal of Trade, Economics and Finance, 2(4), 263-268

Dolapo, A. and Olayeni, P. (2010). The nature of informal house building in Nigeria: A Case Study of Ile-Ife, Nigeria. Conference proceedings of the $4^{\text {th }}$ International Conference on the Built Environment in Developing Countries (ICBEDC 2010) 1st2nd December 2010, Universiti Sains Malaysia 11800 Pulau Pinang, Malaysia. Pp 207-219

Anthonio, J.B. (2002). Housing for all by the year 2015. Paper presented at the 2002 Building Week

Seminar; Obafemi Awolowo University, Ile-Ife, Nigeria.

Baken, R.J. and Van der Linden, J. (1993). "Getting the Incentive Right", Banking on the Formal Private Sector. Third World Planning Review 15(1), 1 - 22
Boamah, N.A. (2010). Housing Affordability in Ghana: A focus on Kumasi and Tamale. Ethiopian Journal of Environmental Studies and Management Vol. 3 No.3 2010

Campbell, A.P., Converse, P.E. and Rodgers, W.L. (1976). The Quality of American Life: Perceptions, Evaluations, and Satisfactions. New York: Russell Sage Foundation

Drakakis-Smith, D. (1981): Housing and the Urban Development Process - Croom Helm, London

Gbadeyan, R.A. (2011). Private Sector's contribution to the Nigerian Housing Market Current Research Journal of Social Sciences 3(2): $104-113$

Gondo, T. (2011). Urban Land and Informality: An Evaluation of Institutional Response Options to Land Informalization in Ethiopian Cities. Retrieved June 8, 2013 from http//www. www.earthsystemgovernance.org/ac2009/paper s/AC2009-0306.pdf

Greene, M. and Rojas, E. (2008). Incremental construction: a strategy to facilitate access to housing. Environment and Urbanization, 20(1), 89-108.

Henshaw, G. (2010). The Role of Private Sector in the Provision of Affordable Housing to the Public Lecture presented to the Nigerian Society of Engineers, CRS Branch

Home, R. and Lim, H. (2004) (eds): Demystifying the Mystery of Capital: Land Tenure and Poverty in Africa and the Carribean, London: Glass House Press.

Ibem, E.O. and Aduwo, E.B. (2012). Public Private Partnerships (PPPs) in Housing Provision in Ogun State, Nigeria: Opportunities and Challenges

Johnson, T.E. (1987). Upward Filtering of Housing Stock: A Study of Upward Filtering of Housing Stock as a Consequence of Informal Settlement Upgrading in Developing Countries. Habitat International 11(1): 173 - 190.

Kabir, B and Bustain, S.A. (2008). A Review of Housing Delivery Efforts in Nigeria

Kieivani, R. and Werna, E. (2001). Modes of Housing Provision in Developing Countries. Progress in Planning, 55: 65 118 
Mabogunje, A. (2003). Welcome Address at the Stakeholders Forum on Strategies for enhancing

Domestic Productrion of Buildig Materials for Mass Hosuign Development held at Nicon Hilton Hotel, Abuja, 24th September 2013

Magigi, W. and Majani, B.B.K. (2006). Housing themselves in Informal Settlement. A Challenge to Community Growth Processes; Land Vulnerability and Poverty Reduction in Tanzania. Promoting Land Administration and Good Governance, 5th FIG Regional Conference Accra, Ghana. March 8 - 11, 2006

Makalle, A.M., Mesaki, S. and Victor, M.A. (2011). Livelihood Opportunities through Informal Housing in the New Capital City of Dodoma, Tanzania. Cross-Cultural Communication, 7(4): $104-120$.

Manija M., Pettang C. and Abanda F. (2011). Urban Self-building Labour Cost modeling in Cameroon, Journal of Construction in Developing Countries, 16(2): 69 - 90.

Mlinga, R.S. and Wells, J. (2002). Collaboration between Formal and Informal Enterprises in the Construction Sector in Tanzania, Habitat International 26 (2002)

Ogunshakin, L. and Olayiwola, L. (1992). The collapse of social housing policy in Nigeria. Habitat International, 16(1): 4153.

Olatubara, C.O. (2008). The Dynamics of Households Residential Choice in Nigeria: The Fifteenth Faculty Lecture, Faculty of the Social Sciences, University of Ibadan, Ibadan, Nigeria.

Onibokun, A.G. (1983). Housing Needs and Responses- A Planner's view Journal of the Nigerian Institute

Onibokun, P. (1990). Urban Housing in Nigeria, Ibadan - NISER

Peter, S. and Ayora, J. (2011). Self-build; Alternative Housing Procurement in remote Indigenous Communities. A report for Centre for Appropriate Technology, Australia

Salau, A.T (1990). The Environmental Context of Urban Housing - Public Services and Infrastructural Facilities in Nigerian Urban Centres. In Onibokun P. (ed.) Urban Housing in Nigeria Ibadan: NISER $58-88$
Siethuraman, S.V. (1985). Basic Needs and the Informal Sector: The Case of Low-Income Housing in Developing Countries; Habitat International, 9(3-4): 299 - 316.

Sivam, A. (2003). Housing Supply in Delhi Cities, Vol 20 No.2, pp $135-141$

Smith, S. (2008). Self-built. Architecture Australia, vol. 97, No.5, pp $81-84$

Stephen, M. (1988): Self-build Housing and the Exploitation of Labour, Housing Studies, 3(4): $247-249$

Syagga, P.M. and Malombe, J. (1995). Development of Informal Housing in Kenya: Case Studies of Kisimu and Nakoro Town. Housing and Building Research Institute, University of Nairobi

Tesfaye, A. (2007). Problems and Prospects of Housing Development in Ethiopia. Property Management, 25(1): 27 - 53

Tipple, G., Korboe, D., Garrod, G. and Willis, K. (1999). Housing Supply in Ghana: A Study of Accra, Kumasi and Berekum. Progress in Planning 51(4): 253 - 324.

Tsenkova, S. (2009), Housing Policy Reforms in Post Socialist Europe, Vienna. Declaration on National Regional Policy and Programmes 2004 on Informal Settlements, updated 18th May, 2009. Physica-Verlag Heidelbeg, Vienna

United Nations Centre for Human Settlement/International Labour Organization (UNCHS/ILO) (1995). Shelter Provision and Employment Generation, ILO Geneva and UNCHS Nairobi

Wells, J. (2001). "Construction and capital formation in less developed economies: Unravelling the informal sector in an African city", in Construction Management and Economics (London, Taylor \& Francis Ltd.), 19, pp. 267-274.

Wells, J. (1999). The construction industry in low income countries: An agenda for research. Paper presented to the International Conference on Construction Industry Development in the New Millenium, held in Singapore, 27-29 Oct., organized by the School of Building and Real Estate, National University of Singapore. 